\title{
TITLE:
}

\section{ON THE POLYP AND MEDUSA OF THE HYDROMEDUSA, GASTROBLASTA CHENGSHANENSIS LING}

$\operatorname{AUTHOR}(\mathrm{S})$ :

Sugiura, Yasuo

\section{CITATION:}

Sugiura, Yasuo. ON THE POLYP AND MEDUSA OF THE HYDROMEDUSA, GASTROBLASTA CHENGSHANENSIS LING. PUBLICATIONS OF THE SETO MARINE BIOLOGICAL LABORATORY 1973, 20: 209-220

\section{ISSUE DATE:}

1973-12-19

URL:

http://hdl.handle.net/2433/175776

RIGHT: 


\title{
ON THE POLYP AND MEDUSA OF THE HYDROMEDUSA, GASTROBLASTA CHENGSHANENSIS LING
}

\author{
YASUO SUGIURA \\ Biological Laboratory, Dokkyo University, Soka-Shi, Saitama-Ken, Japan 340
}

With 7 Text-figures

Gastroblasta chengshanensis LING is a medusa belonging to the Leptomedusae, which is commonly found in Japan. This medusa is characterised by having more than one manubrium and multipling by fission (Figs. 6A and 6B). Concerning the mode of fission of this medusa, or those of other species of the same genus, there have been published several reports.

In the present paper, the multiplication of medusae by fission, especially as it is affected by temperature, will be described, based on the occurrences of the medusae in the sea and experiments in the laboratory.

In addition, some notes are given on the polyp of this medusa, which the author obtained from the planulae reared in the laboratory.

\section{Acknowledgements}

The author would like to acknowledge the continuous guidance and many valuable advices of Professor Emeritus T. UCHIDA, Hokkaido University. He also wishes to express his thanks to Dr. M. YAMADA, Hokkaido University and Dr. Z. NAGAO, Hokkaido University of Education, for their helpful suggestions. The author is indebted to Dr. J. C. DAN, Ochanomizu Women's University, for very valuable guidance to revise the English manuscript and to Dr. K. DAN, president of Tokyo Metropolitan University, for incessant encouragement. Thanks are due to Dr. E. HIRAI and Dr. Y. KAKINUMA, Marine Biological Station of Asamushi, for their kind supports, and also to the director and staff of Misaki Marine Biological Station for the use of facilities and for providing with the data of the sea water temperature. Further, he wishes to express his obligation to the staff of Biological Laboratory, Dokkyo University, for their assistance.

\section{Effects of Temperature on the Fission of Gastroblasta chengshanensis}

\section{Observations and Experiments}

(A) Occurrences of the Medusa in the Sea and the Water Temperature

From November 1969 to October 1972, surface plankton samples were collected once a week at the entrance to the cove of Aburatsubo, Misaki, Kanagawa Prefecture. The net, $30 \mathrm{~cm}$ in diameter and GG 34 in mesh, was hauled for 30-40 minutes at each time. The days of occurrences of medusae and the sea water temperature are 


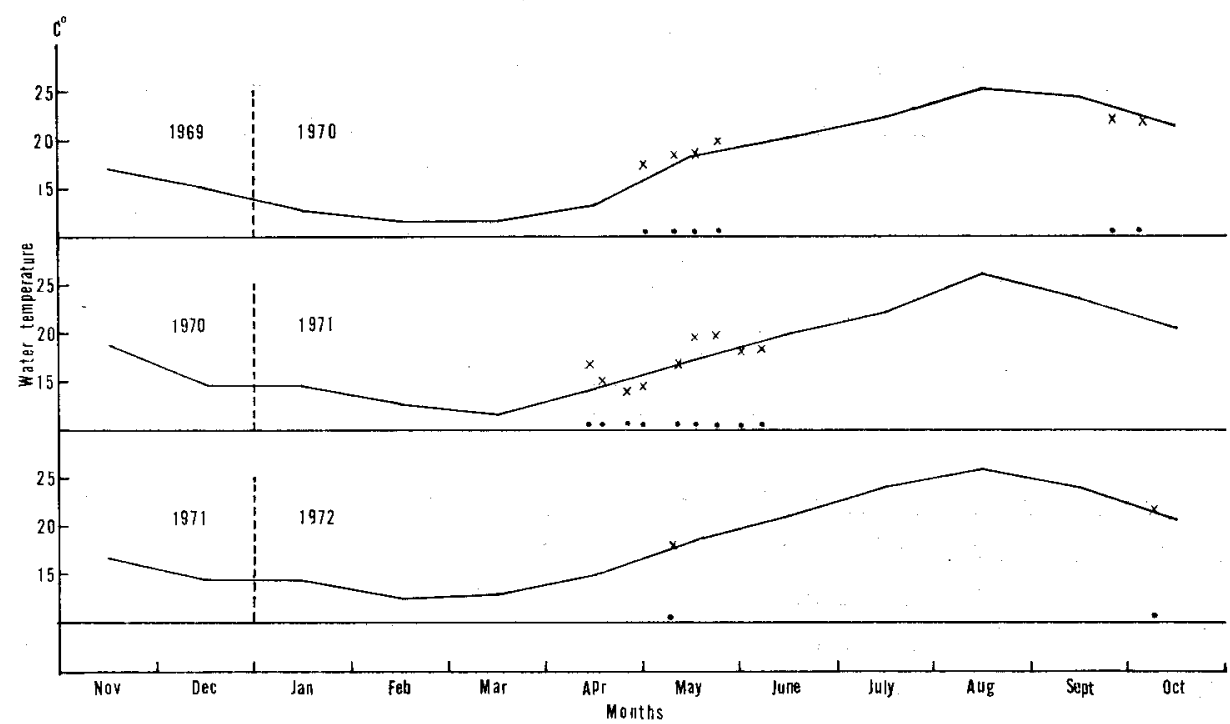

Fig. 1. Relation between the occurrences of the medusae and the sea water temperature near Misaki.

- Seasonal change in the sea water temperature at the Misaki Marine Biological Station.

$x$ Seawater temperature at the time when the medusae were captured.

- Day when the medusae were captured.

shown in Fig. 1. The maximum and minimum water temperatures recorded annually at the Misaki Marine Biological Station are respectively $26^{\circ} \mathrm{C}$ and $12^{\circ} \mathrm{C}$. In all 3 years, the water temperature when the medusae first appeared was $17^{\circ} \mathrm{C}$. In 1970 , the medusae were continuously found from May 2 to May 24 in spring, followed by September 26 and October 4 in autumn. The number of medusae collected in each haul during the spring was about 30 at the maximum, 2 at the minimum, and 14 on an average, while during the autumn it was only 1 and 2 . In 1971, medusae were again collected from April 13 to June 6, but no medusae were found in other seasons. The water temperature generally ranged between 14.5 and $19.7^{\circ} \mathrm{C}$ during this period, although an unexpectedly high temperature, $16.5^{\circ} \mathrm{C}$, was recorded on April 13. On most days except May 30 and June 6, 30-60 individuals were found during this season. In 1972, however, medusae were collected only twice, on May 7 and October 8 . On May 7, the water temperature was $17.8^{\circ} \mathrm{C}$, and only 4 medusae were collected and on October 8 , only a single medusa was obtained at $21.5^{\circ} \mathrm{C}$. Individuals collected in the sea were $2-5 \mathrm{~mm}$ in diameter of the umbrella with 2-3 manubria.

\section{(B) Laboratory Experiments}

Materials: Medusae obtained in May 1970 and from April to May 1971 at the entrance to the cove of Aburatsubo, Kanagawa Prefecture, were carried to the laboratory located about $80 \mathrm{~km}$ from the sea. The stock of medusae was maintained by 
keeping about 20 medusae in each of petridishes, $90 \mathrm{~mm}$ in both diameter and height and filled with sea water to $60 \mathrm{~mm}$ deep, feeding with newly hatched brine shrimps, about 10 per medusa, and renewing the water every 3 or 4 days. The water temperature was constantly kept at $17-18^{\circ} \mathrm{C}$ for 18 months, from May 1970 to October 1971 , and at $13-14^{\circ} \mathrm{C}$ for 12 months, from November 1971 to October 1972. Materials for experiments were provided from these dishes at need.

Experiments $(a)$ : To see the relation between the water temperature and the rate of fission, two experiments were carried out as follows:

(1) The rate of fission was observed on medusae cultured in mass or individually at a constant water temperature of $13-14^{\circ} \mathrm{C}$ or $17-18^{\circ} \mathrm{C}$.

(2) Mass cultures were subjected to an increase in water temperature from $13-14^{\circ} \mathrm{C}$ to $17-18^{\circ} \mathrm{C}$ or $21-22^{\circ} \mathrm{C}$, and its effect on the rate of fission was observed.

Mass culturing was performed in the same way as the stock was maintained. Individual culturing was carried out as follows. In each experiment, individuals with 1-4 manubria were kept one in each of 8 dishes of $37 \mathrm{~mm}$ in diameter, $68 \mathrm{~mm}$ in height, and filled with sea water to $50 \mathrm{~mm}$ deep; feeding and renewing of the water were done as in mass cultures. Observations were made once a day during about 3 weeks to record fissions occurred including measurement of the size of the daughter individuals and the number of manubria in them. The daughter medusae were removed into separate dishes.

The result of the experiment (1): Only a few fissions occurred in mass cultures of medusae, which were kept at a constant temperature of $13-14^{\circ} \mathrm{C}$. In 6 cultures including 120 individuals, only 17 fissions were observed in 46 days. When the medusae are kept at a low temperature, many of them are apt to show an increase in size and in the number of manubria as their fission is suppressed (Fig. 6C). For example, one of them was $14 \mathrm{~mm}$ in diameter of the umbrella and provided with 23 manubria.

Individual cultures of medusae derived from 8 individuals were maintained at constant low and high water temperatures for 21 days. The average number of fissions was 6 in 4 experiments at $13-14^{\circ} \mathrm{C}$ and 44 in the same number of experiments at $17-18^{\circ} \mathrm{C}$.

The result of the experiment (2): When medusae which had been kept at $13-14^{\circ} \mathrm{C}$ for a long time were subjected to higher temperatures, $17-18^{\circ} \mathrm{C}$ or $21-22^{\circ} \mathrm{C}$, for 8 days a marked increase in number of fissions was observed as shown in Fig. 2. The medusae began to divide after only a day at higher temperatures and their number rapidly increased with time. Eight days were required to double the number of medusae at $17-18^{\circ} \mathrm{C}$ and 4 days in 2 of the runs at $21-22^{\circ} \mathrm{C}$. Although the curve marked with triangles in the lower chart of Fig. 2 did not show any increase in number of medusae from the 4 th to 7 th day, the influence of temperature on fission did not differ essentially from the other cases, rather it seemed more active, as the medusae were having a very large number of manubria during this period. 

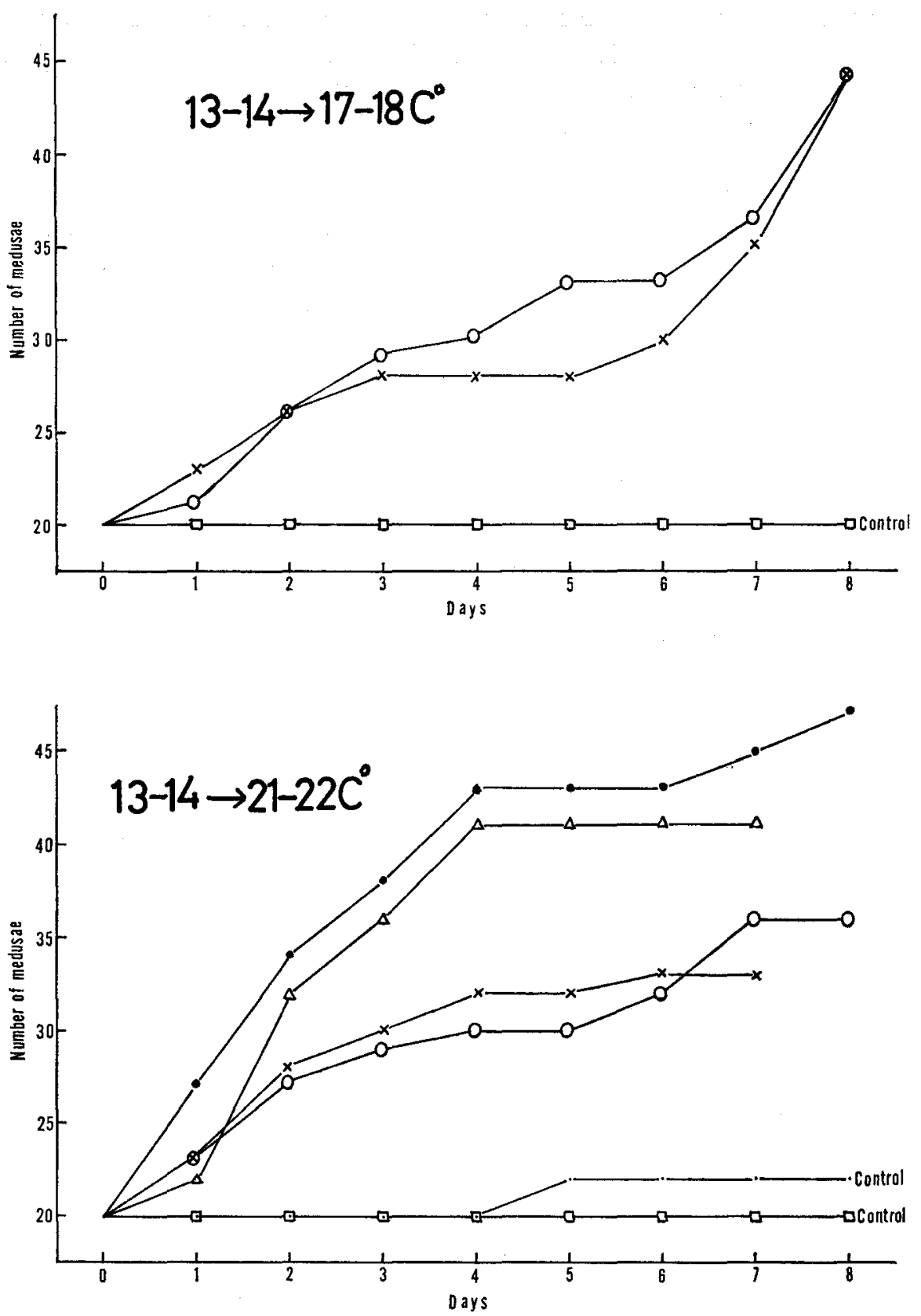

Fig. 2. Daily increase in number of medusae subjected to an increase in water temperature from $13-14^{\circ} \mathrm{C}$ to $17-18^{\circ} \mathrm{C}$ (top) or $21-22^{\circ} \mathrm{C}$ (bottom). 
Experiments $(b)$ : Fission in medusae kept continuously at $17-18^{\circ} \mathrm{C}$. From the results of the observations in the sea and laboratory, it is considered that the respondence of medusae to the water temperature in fission begins at a threshold of about $17-18^{\circ} \mathrm{C}$. On this consideration, a few observations were made on medusae cultured individually at the above-mentioned temperature range with respect to: (1) the number of manubria at the time when fissions occured in mother individuals, (2) the number of manubria in daughter individuals, and (3) the interval between fissions.

As shown in Fig. 3, division occurred most frequently in medusae with 3 manubria, followed 4, 2 and 5. The way of sharing the manubria of mother individuals between daughters is shown in Table 1. The observations were made every day, and it was found that not only 2 but also 3, and sometimes even 4 divisions were performed in a day. The ratio of 1 to 3 fissions per day was $116: 32: 2$ in the experiments. When successive divisions produced 3 medusae in a day, one of the 2 daughters of the first division was likely to bud off a small medusa having no manubrium. About $20 \%$ of the 150 individuals lacked the manubrium in the experiments and a half of these mouthless individuals were the results of such a process. Such medusae without any manubrium were fairly small, as $1-2 \mathrm{~mm}$ in diameter (Fig. 6D). Since they can take

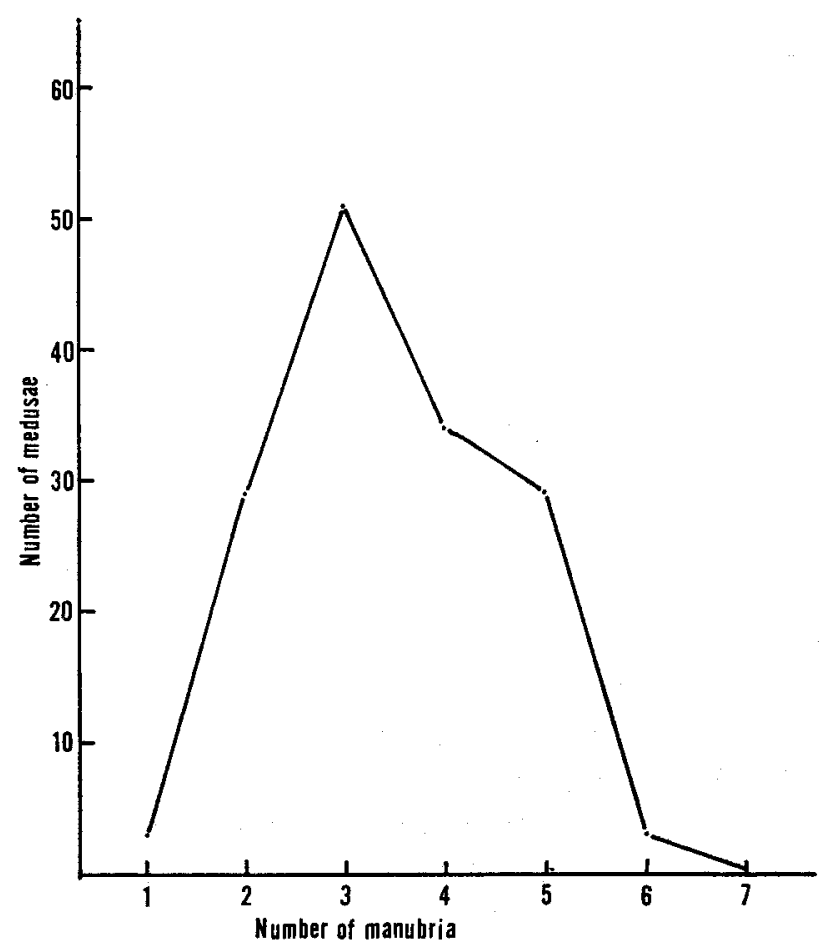

Fig. 3. Number of manubria in mother medusae at the time when fission occurred at $17-18^{\circ} \mathrm{C}$. 
Table 1. The way of sharing the manubria of mother medusae between daughters, at $17-18^{\circ} \mathrm{C}$.

\begin{tabular}{|c|c|c|c|c|c|c|}
\hline \multirow{3}{*}{$\begin{array}{l}\text { Number of } \\
\text { manubria in } \\
\text { mother } \\
\text { medusae }\end{array}$} & \multicolumn{6}{|c|}{$\begin{array}{c}\text { Number of manubria in daughter medusae (a) and } \\
\text { number of examples (b) }\end{array}$} \\
\hline & \multicolumn{2}{|c|}{1 fission } & \multicolumn{2}{|c|}{2 fissions } & \multicolumn{2}{|c|}{3 fissions } \\
\hline & $\mathrm{a}$ & $b$ & a & b & $\mathbf{a}$ & b \\
\hline 1 & $1: 0$ & 3 & & & & \\
\hline 2 & $\begin{array}{l}2: 0 \\
1: 1\end{array}$ & & $1: 1: 0$ & 5 & & \\
\hline 3 & $\begin{array}{l}3: 0 \\
2: 1\end{array}$ & $\begin{array}{r}3 \\
37\end{array}$ & $\begin{array}{l}2: 1: 0 \\
1: 1: 1\end{array}$ & $\begin{array}{l}5 \\
6\end{array}$ & $\because$ & \\
\hline 4 & $\begin{array}{l}4: 0 \\
3: 1 \\
2: 2\end{array}$ & $\begin{array}{r}1 \\
9 \\
16\end{array}$ & $\begin{array}{l}2: 2: 0 \\
2: 1: 1\end{array}$ & $\begin{array}{l}2 \\
5\end{array}$ & $3: 1: 1: 0$ & 1 \\
\hline 5 & $\begin{array}{l}5: 0 \\
4: 1 \\
3: 2\end{array}$ & $\begin{array}{r}2 \\
6 \\
12\end{array}$ & $\begin{array}{l}4: 1: 0 \\
3: 1: 1 \\
2: 2: 1\end{array}$ & $\begin{array}{l}1 \\
1 \\
6\end{array}$ & $2: 1: 1: 1$ & 1 \\
\hline 6 & $\begin{array}{l}5: 1 \\
3: 3\end{array}$ & $\begin{array}{l}1 \\
2\end{array}$ & & & & \\
\hline 7 & & & $4: 3: 0$ & 1 & & \\
\hline & & $\begin{array}{l}116 \\
\left.\frac{15}{16}\right)\end{array}$ & & & & 2 \\
\hline
\end{tabular}

* $\left(\frac{\mathrm{B}}{\mathrm{A}}\right)$ A: Total number of medusae. B: Number of the medusae lacking manubrium.

no food, most of them inevitably fail to develop and tend to die about 10 days after fission. The intervals between fissions showed a range from 1 to 11 days for the great majority of individuals as seen in Fig. 4.

\section{Discussion}

KomaI and YAMAZI (1944) reported that the medusae of Gastroblasta chengshanensis were unusually abundant along the coast of the Kii Peninsula from spring to early summer in 1942 and 1943. In Misaki, during the past 3 years, the medusae were collected in the same season, although the span of the period and the number of medusae collected differed strikingly between 1971 and 1972. These observations show evidently that an annual irregularity in the population size of medusae may be natural. The distribution of this medusa in Japan is fairly wide, extending from Hokkaido to Kyushu. Thus, it is possible that this medusa might be acclimatized differently to temperature from a locality to another. Anyhow, the surface water temperature at the time when the medusae were found in the vicinity of Misaki was 


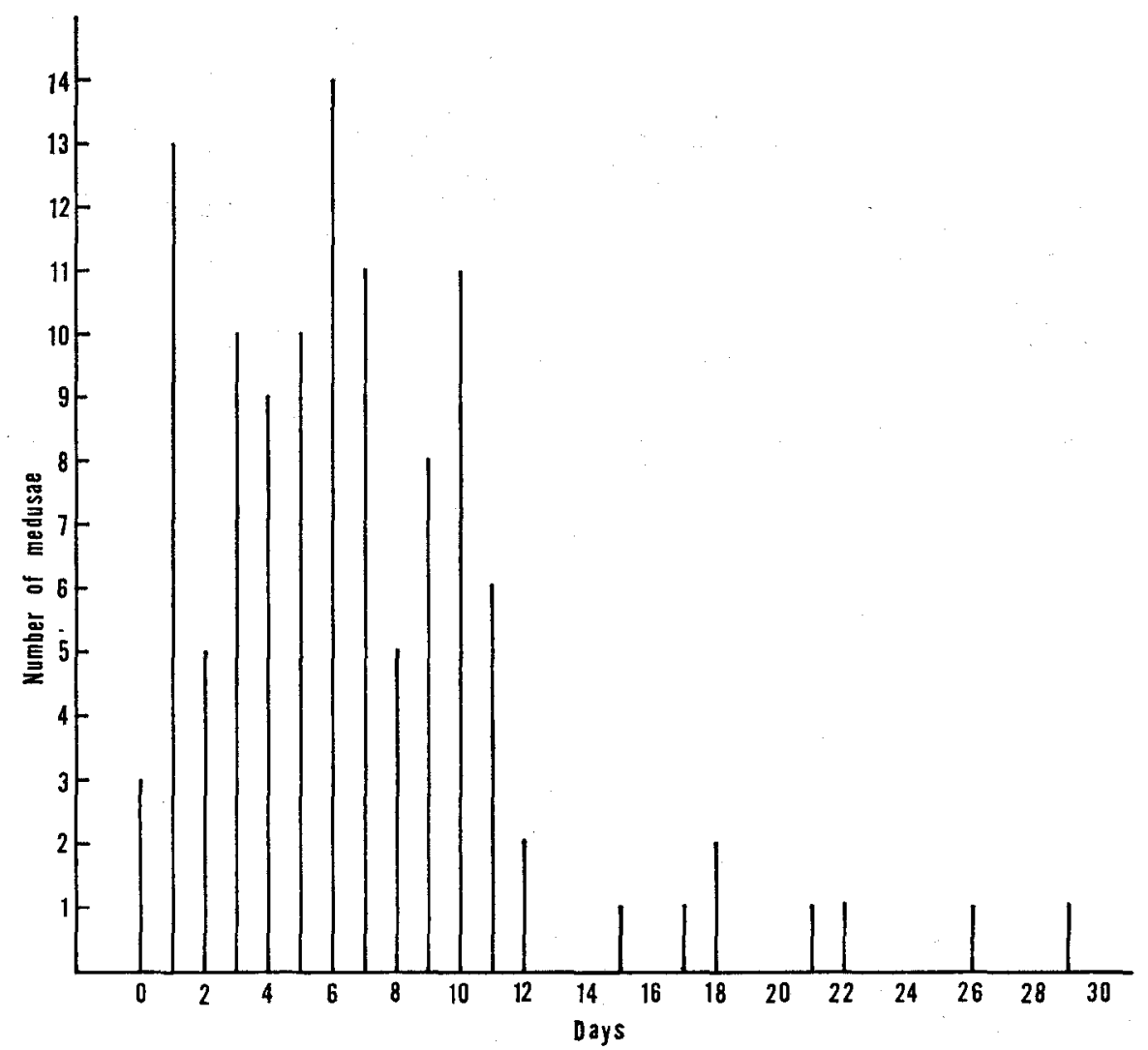

Fig. 4. Interval (days) between fissions in medusae kept continuously at $17-18^{\circ} \mathrm{C}$.

$17-18^{\circ} \mathrm{C}$ and the fission was markedly increased by raising the water temperature from $13-14^{\circ} \mathrm{C}$ to $17-18^{\circ} \mathrm{C}$ in the laboratory. Consequently, it seems to be appropriate to consider that the appearance of medusae in nature is attributable to the multiplication by fission, which is affected by the seasonal rise in water temperature. On the basis of the fact that medusae collected from the sea were nearly the same in size and provided with the same number of manubria as those maintained at a given water temperature in the laboratory, it may be suggested that the fission occurs most frequently in medusae with 3 manubria. Considering from the results of indoor experiments, it is within the bounds of possibility that this medusa may survive the minimum water temperature of $12{ }^{\circ} \mathrm{C}$ at Misaki, but the fact that no specimens having many manubria have been collected during the winter must have its own reasons.

\section{On the Polyp of Gastroblasta chengshanensis}

As far as the author is aware, no paper has been published on the polyp of Gas- 

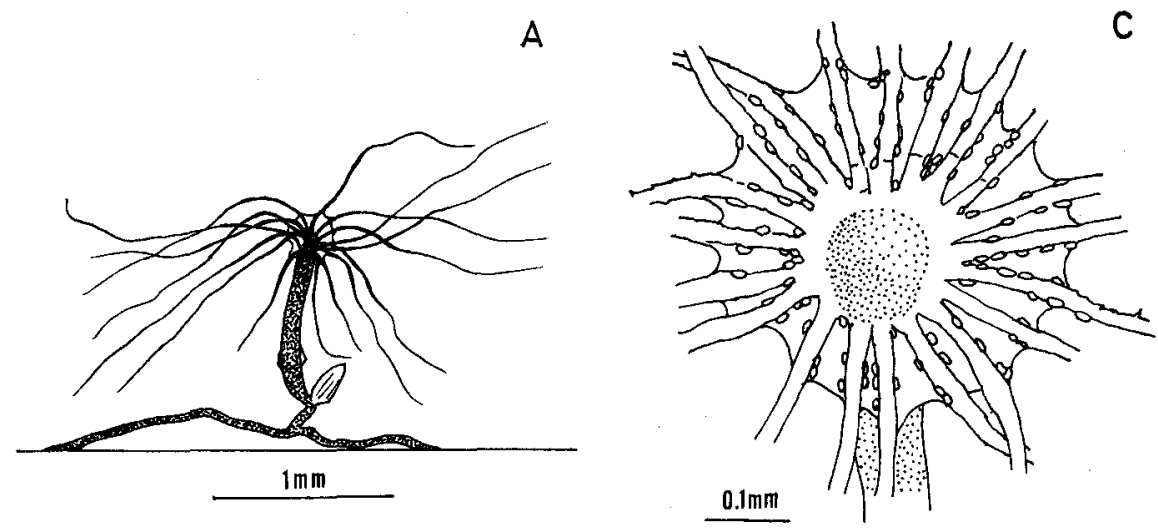

B
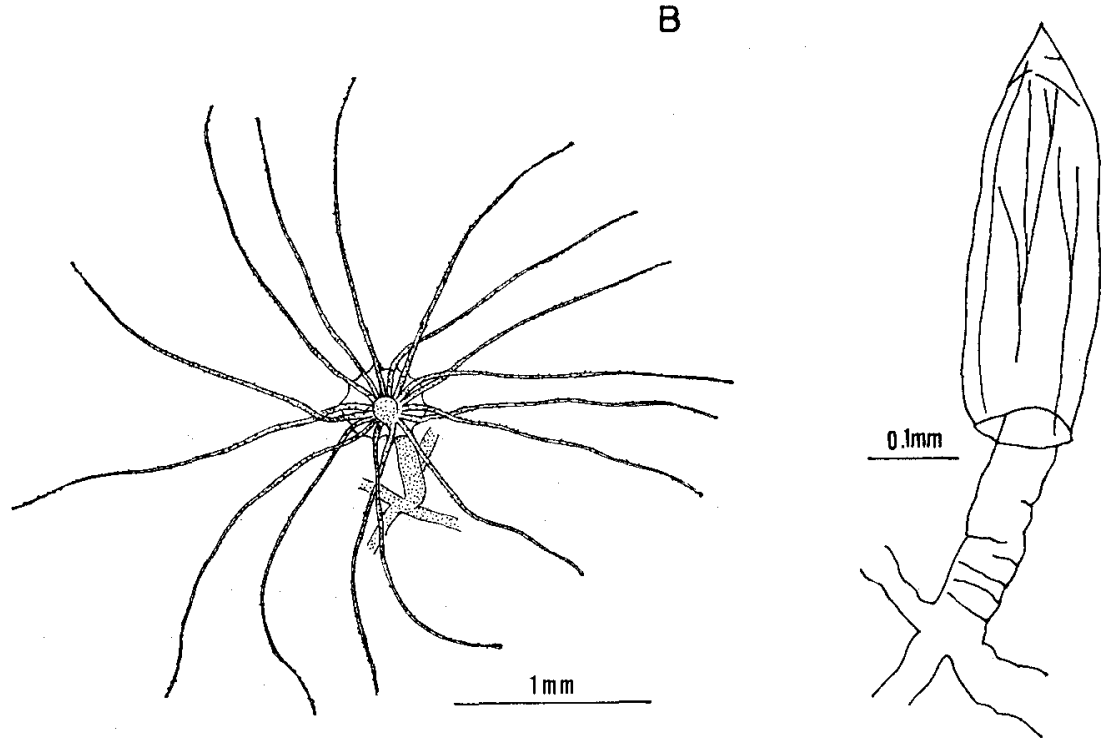

Fig. 5. A: Polyp of Gastroblasta chengshanensis

B: Fully expanded polyp

C: Web

D: Hydrotheca and hydrocaulus, from a degenerated individual

troblasta chengshanensis. In the process of rearing the medusae in the laboratory, he found planulae, about $0.15 \mathrm{~mm}$ in length, in the dishes containing mature medusae (Figs. 6E and 6F). The planulae were removed to other dishes containing loose meshes of cotton fibers to restrict their movement and there a few cases of attachment were observed. After 2 days, the attached planulae elongated and changed into single juvenile polyps each with 8 short tentacles (Fig. 7A). Larger polyps are about $1 \mathrm{~mm}$ in height. Polyps are connected one another by stolons creeping on the glass surface 


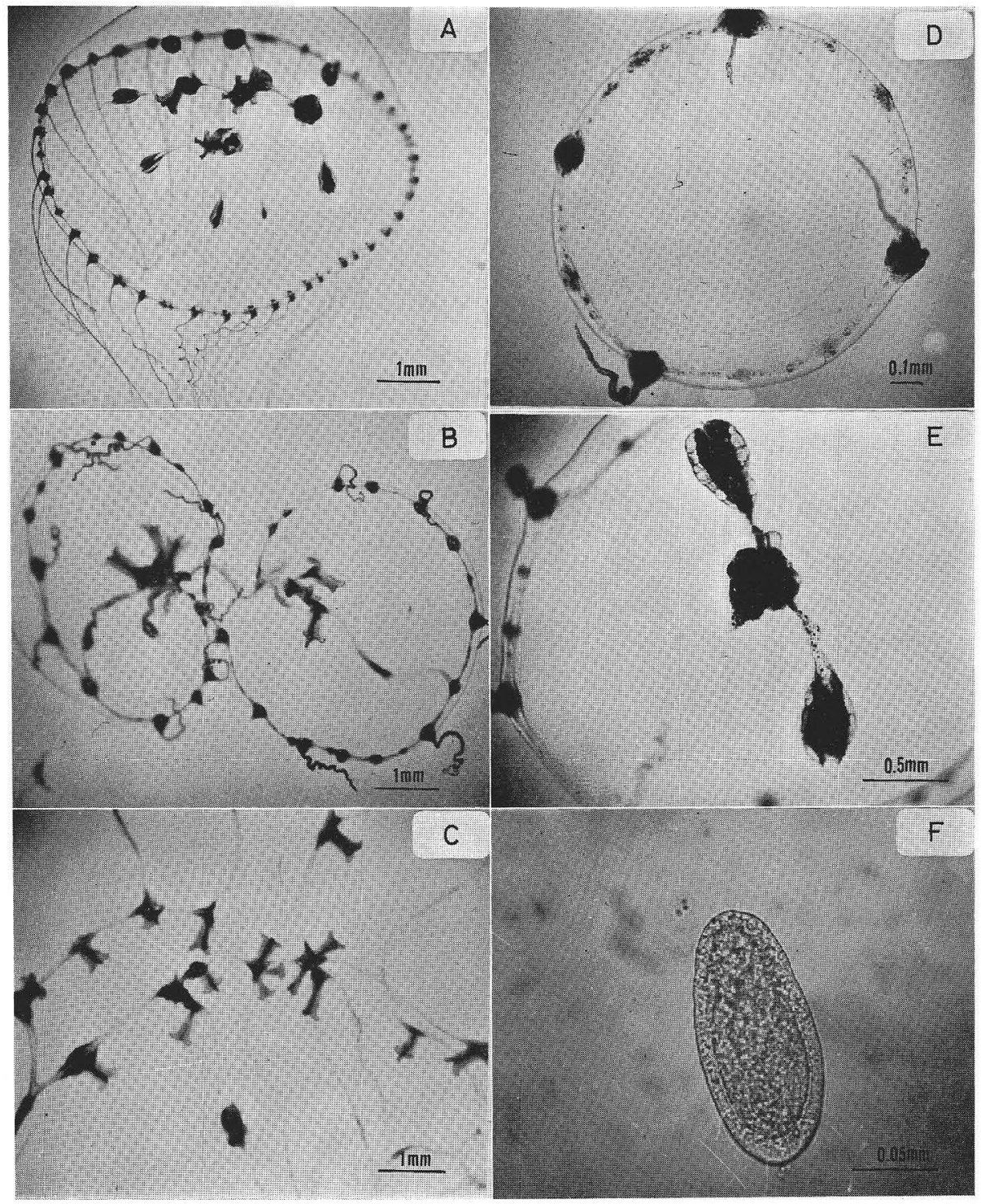

Fig. 6. A: Medusa of Gastroblasta chengshanensis

B: Medusa being divided into 2 daughter individuals

C: Large medusa with numerous manubria

D: Small medusa without manubrium

E: Mature medusa with ovaries

F: Planula

(Fig. 7B). The hydranth is colourless and with filiform tentacles, commonly 14-16 and 20 at the maximum in number and longer ones extending to $1.2-2.0 \mathrm{~mm}$ (Figs. 5A and 5B, Fig. 7C). Their proximal portions, to about one-tenth of the total length, 


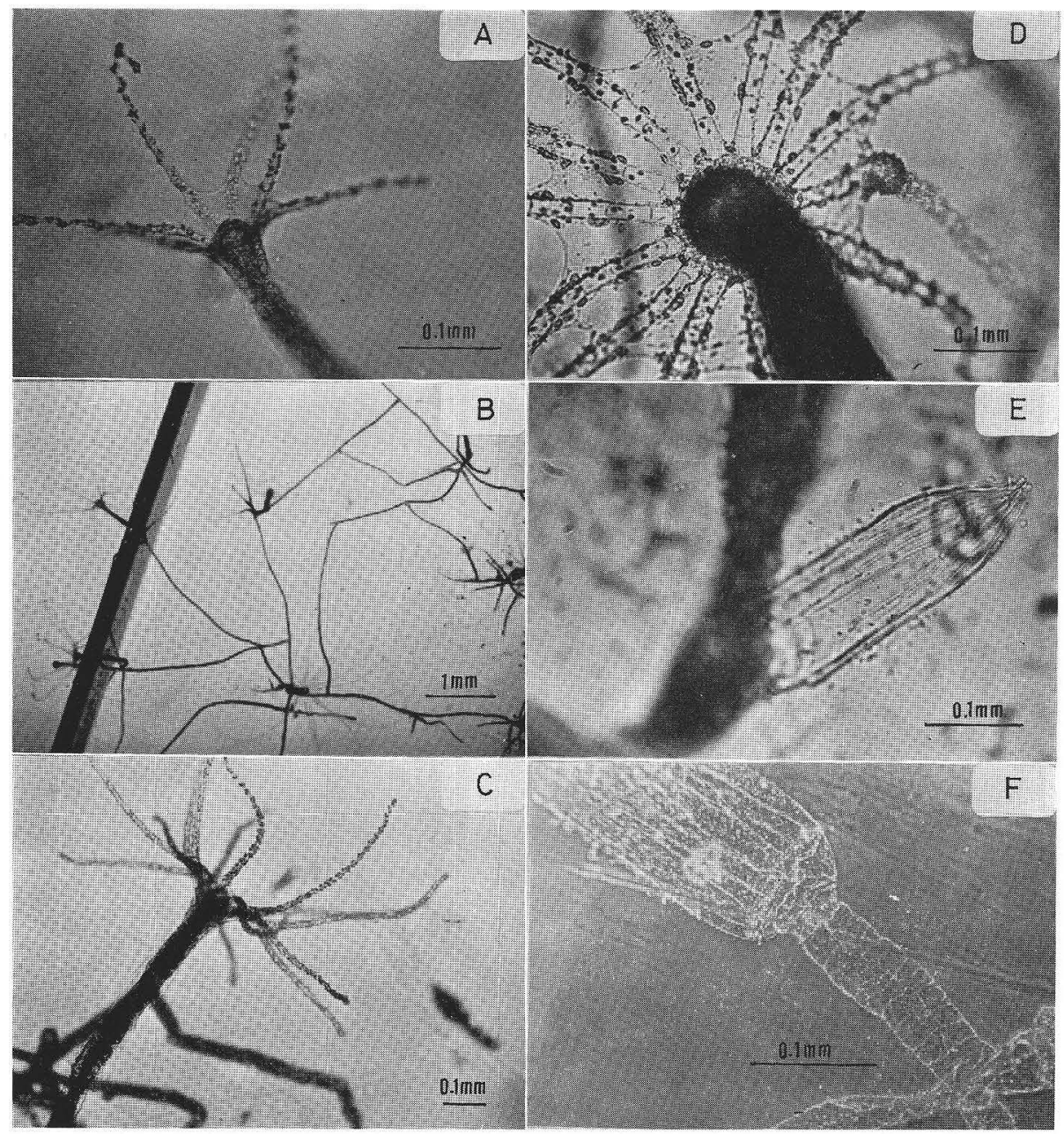

Fig. 7. A: Juvenile polyp of Gastroblasta chengshanensis
B: Colony of hydroids
C: Developed polyp; tentacles are not fully expanded in this figure
D: Web
E: Hydrotheca, from a degenerated individual
F : Hydrocaulus, from a degenerated individual

are connected by a membranous web and furnished with conspicuous bean-like nematocysts (Fig. 5C, Fig. 7D). The hydrotheca is cyrindrical and tapers to an apical point, $0.30-0.45 \mathrm{~mm}$ in length and $0.07-0.14 \mathrm{~mm}$ in breadth, and the toothed opercular part is not conspicuous (Fig. 5D, Fig. 7E). The hydrocaulus is generally shorter than the hydrotheca and faintly annulated (Fig. 7F). No gonophore could be seen during 13 months of observation. Although the medusa of this species has been considered to be related closely to that of Clytia, the polyp is rather similar to 
that of Aequorea coerulescens, which was reported by KAKINUMA (1966) and UCHIDA (1968).

The embryology and life history of this species will be reported in a further paper.

\section{Summary}

1. The relation between the occurrence of the medusa of Gastroblasta chengshanensis and the sea water temperature was studied during the past 3 years in the coastal waters of Misaki.

2. The water temperature at the time when the medusae were found was $17-18^{\circ} \mathrm{C}$.

3. Very few cases of fission were found among the medusae which were kept continuously at a constant temperature of $13-14^{\circ} \mathrm{C}$.

4. When the medusae cultured at $13-14^{\circ} \mathrm{C}$ were subjected to higher water temperature of $17-18^{\circ} \mathrm{C}$ or $21-22^{\circ} \mathrm{C}$, a marked increase in number of fissions was observed.

5. A few experiments were performed to see the mode of fission in the medusae kept constantly at $17-18^{\circ} \mathrm{C}$.

6. The morphology of the polyp of Gastroblasta chengshanensis was studied.

\section{REFERENCES}

Kakinuma, Y. 1966. Life cycle of a hydrozoan, Campanulina type or Aequorea coerulescens. Bull. Mar. Biol. St. Asamushi, Tohoku Univ. 12, 211-218.

Komai, T. and YAMAZI, I. 1944. The asexual reproduction of the Hydromedusa Gastroblasta chengshanensis. Ann. Zool. Jap. 22, 105-108.

Kramp, P. L. 1961. Synopsis of the medusae of the world. Jour. Mar. Biol. Ass. U. K. 40, 1-469.

LANG, A. 1886. Gastroblasta Raff:zelei. Eine durch eine Art unvollständiger Theilung entstehende Medusen-Kolonie. Jena. Zeitsch. Naturwiss. 19, 735-763.

LING, S. W. 1937. Studies on Chinese Hydrozoa. 1. On some Hydromedusae from the Chekiang coast. Peking Nat. Hist. Bull. 2, 351-365.

Mayer, A. G. 1910. Medusae of the world. 2. Hydromedusae. Carnegle Inst. Washington. 231-498.

Russell, F. R. S. 1954. The Medusae of the British Isles. Cambridge., 1-530.

UCHIDA, T. 1925. Some hydromedusae from northern Japan. Jap. Jour. Zool. 1, 77-100.

Uchida, T. 1968. The two leptomedusae, Aequorea coerulescens and Aequorea vitrina. Jour. Fac. Sci., Hokkaido Univ. Ser. 6, Zool. 16, 359-368.

West, D. L. and Renshaw, R. W. 1970. The life cycle of Clytia attenuata. Mar. Biol. 7, 332-339.

\section{DISCUSSION}

UCHIDA: The medusa is closely allied to that of Clytia, but the hydroid belongs to the Campanulinidae. How do you think about the systematic position of the hydroid?

Sugrura: As the gonangia and medusae are not yet observed, I feel some difficulty to explain about the systematic position. At present, I think that the hydroid is rather similar to that of the Aequoreidae. 
WERNER: Have the polyps in your cultures produced gonangia and medusae? Sometimes, the relationship becomes clear by the shape of the gonangium.

SUGIURA: Unfortunately, no gonangia and medusae could be seen. I agree with you in thinking that the observations on them are the most important subject in future studies.

MACKIE: Is temperature the only critical factor in causing division or could availability of food be partly responsible? In another Leptomedusan, Phialidium, Dr. E. Roosen Runge has evidence that food availability is the critical factor in medusogenesis.

SUGrURA: I don't think temperature is the only critical factor in causing division. Further studies shall be made on food availability in future. 